\title{
APPLICATION OF SOLID-PHASE RADIOIMMUNOASSAY IN THE DIAGNOSIS OF AUJESZKY'S DISEASE IN NATURALLY INFECTED PIGS
}

\author{
L. RODÁK, B. ŠMÍD, A. HOLUB, M. SEDLÁČEK \\ Veterinary Research Institute, 62132 Brno
}

Received August 24, 1981

\begin{abstract}
Rodák L., B. Šmíd, A. Holub, M. Sedláček: Application of Solid-Phase Radioimmunoassay in the Diagnosis of Aujezsky's Disease in Naturally Infected Pigs. Acta vet. Brno, 50, 1981: 213-220.

The development and use of a solid-phase radioimmunoassay (RIA) in the diagnosis of Aujeszky's disease in naturally infected pigs is described. The method is based on the determination of specific antiviral antibodies in the blood serum. Compared with the routinely employed virus-neutralization test, the RIA method is more rapid to perform, does not require aseptic conditions and yields antibody titres approximately 10000 times higher. It has potential as a diagnostic tool in the field.
\end{abstract}

Specific antiviral antibodies, Herpesvirus infection, ${ }^{125}$ I-labelled antibody to swine IgG.

In viral infections, a rise in humoral antibody titres occurs already during the acute phase of the disease and the antibodies are demonstrable by serological methods for a considerable length of time after infection. The viral agent, on the other hand, can often be isolated and identified only during the initial phase of the disease. Therefore serological methods are the basic and most widely used tools in the diagnosis of viral diseases provided that the virus has been isolated and can be propagated to yield the appropriate antigen. Nevertheless, even the serological methods that have been used most widely in virology incur much time and effort and their sensitivity and specificity may be affected by a number of factors.

The aforementioned disadvantages of the conventional methods for detection of antiviral antibodies are removed by radio- and enzymimmunoassay. In one of its modifications, known as solid-phase radioimmunoassay, one component of the reaction - either viral antigen or antibody is bound to a solid support. As the solid support of antigen (virus, virus-infected cell cultures) or antibody, wells of polystyrene or polyvinyl chloride microtitre serological plates have generally been used. The bulk of evidence has shown quite convincingly that these methods have several advantages in the diagnosis of infectious diseases, since they are highly specific, rapid to perform and more than thousandfold more sensitive than other techniques. They have been used for the detection of antibodies against hepatitis A, herpes simplex, smallpox, rabies, rubella, measles, influenza $A$ and other viruses (Hutchison and $Z$ iegler 1972, 1974, Rosenthal et al. 1972, Smith et al. 1974, Patterson and Smith 1975, Forghani et al. 1975, 1976, Purcell et al. 1976, Arstila et al. 1977, Meurman et al. 1977a, b, Kalimo et al. 1977). Because of their considerable merits these methods have been used in radioimmunoassay (RIA) (Kelling et al. 1978, Rodák et al. 1978, Döller and Jakubik 1980) and enzyme linked immunosorbent assay (ELISA) (Briaire et al. 1979, Toma et al. 1979) for the diagnosis of Aujeszky's disease of pigs. The present study is an extension of our previous observations on the use of RIA in experimentally infected piglets (Rodák et al. 1978) and demonstrates its applicability to the diagnosis of Aujeszky's disease in naturally infected pigs. 
Sera

\section{Materials and Methods}

Blood serum samples were supplied by the State Veterinary Institute. They were taken from 96 sows and 2 boars on a co-operative farm where Aujeszky's disease occurred in the clinical form. The herd had no previous history of this disease and the animals had not been vaccinated for it. The presence of the disease was confirmed by isolation of the virus and by the results of virus-neutralization (VN) tests which were made available to us by the State Veterinary Institue.

\section{Viral and Control Antigen}

Pig kidney cell cultures were grown in Roux bottles with Eagle's minimal essential medium (MEM) supplemented with 10 per cent $(v / v)$ inactivated calf serum. After a confluent cell sheet was formed (in about 2 days), the cells were washed with maintenance medium (Earle's medium without serum) and infected with Aujesky's disease (AD) virus. After cytopathic effect was observed, the cells in the medium were homogenized three times by repeated freezing and thawing. The infectivity titre of the cell homogenate was generally $10^{7-8} \mathrm{TCID}^{50} / \mathrm{ml}$. The same procedure was used to prepare the homogenate of control non-infected cells. Hereafter, the homogenates of infected and non-infected cells will be referred to as viral and control antigen, respectively. The two antigens were dispensed into ampoules which were then sealed and stored at $-70^{\circ} \mathrm{C}$. The antigens thus prepared can be used for a number of months or even years. The RIA test does not require the use of concentrated antigens. Under the conditions of our study, very good results were obtained with antigens diluted $1: 20$ to $1: 100$. However, the routine practice in this study was to use antigens diluted $1: 5$ with $0.05 \mathrm{~mol} / 1\left(\mathrm{NH}_{4}\right)_{2} \mathrm{CO}_{3}$.

\section{Preparation and Labelling of Rabbit Anti-Swine IgG}

Pig serum was precipitated three times with 40 per cent saturated ammonium sulphate. The precipitated Ig fraction was dissolved, dialyzed thoroughly against $0.1 \mathrm{~mol} / 1 \mathrm{Tris}-\mathrm{HCl}$ containing $0.05 \mathrm{~mol} / 1 \mathrm{NaCl}, \mathrm{pH}=8.3$, and then purified on a column of DEAE Sephadex A-50 equilibrated with the same buffer. Immunoelectrophoresis confirmed that the protein eluted was pure IgG.

IgG thus prepared was used to immunize rabbits. The first injection of swine $\operatorname{IgG}$ ( 1 to $2 \mathrm{mg}$ ) in Freund's complete adjuvant was given intradermally in the back at six sites. A second injection was given $\mathrm{i} / \mathrm{m}$ one month later and was followed by another $\mathrm{i} / \mathrm{m}$ injection after a lapse of 10 days. The rabbits were exsanguinated 10 days after the last injection. When checked immunoelectrophoretically with pig serum, the rabbit antiserum formed one precipitation line against swine IgG in the IgG region.

The antiserum obtained was precipitated with 40 per cent saturated ammonium sulphate. Specific antibodies were prepared from crude IgG fraction by separation in CNBr Sepharose 4B (Pharmacia, Sweden) with covalently bound swine IgG. The antibodies eluted with $0.1 \mathrm{~mol} / 1$ glycine buffer, $\mathrm{pH}=2.8$. Specific anti-swine IgG thus obtained were concentrated, dialyzed against borate buffer, $\mathrm{pH}=8.0$, dispensed into ampoules in $0.5 \mathrm{mg}$ quantities and freeze-dried. The labelling of specific antibodies was made by chloramine-T method as modified by $\mathrm{McCo}$ nahey and Dixon (1966). The specific activity of ${ }^{125}$ I-labelled antibodies was $37-370 \mathrm{KBq} / \mu \mathrm{g}$ $(1-10 \mu \mathrm{Ci} / \mu \mathrm{g})$. The stock solution of ${ }^{125} \mathrm{I}$-labelled antibodies in phosphate buffered saline (PBS), $\mathrm{pH}=7.2$, containing 1 per cent rabbit serum albumin was dispensed into test tubes. Stored at $-20^{\circ} \mathrm{C}$, it could be used for at least 4 months after labelling.

\section{The RIA technique}

$50 \mu \mathrm{l}$ volumes of viral and control antigen, diluted $1: 5$ with $0.05 \mathrm{~mol} / 1\left(\mathrm{NH}_{4}\right)_{2} \mathrm{CO}_{3}$ were dispensed in triplicate into wells of polyvinyl chloride plates and were allowed to be adsorbed for 18 hours at $4{ }^{\circ} \mathrm{C}$. The wells were then washed with PBS supplemented with 0.1 per cent Tween 80 (PBS + Tween), and $50 \mu 1$ volumes of the test pig serum diluted with PBS containing 0.5 per cent bovine serum albumin (BSA) were added to all wells. The test sera were diluted either threefold over the range of $1: 10-1: 196.830$ or uniformly $1: 100$. During the first incubation with the test serum $\left(2 \mathrm{hrs}\right.$ at $\left.20^{\circ} \mathrm{C}\right)$ pig serum antibodies were bound to the antigens. The wells were then washed three times with PBS + Tween. During a second incubation $\left(2 \mathrm{hrs}\right.$ at $\left.20^{\circ} \mathrm{C}\right)$ ${ }^{125}$ I-labelled specific anti-swine IgG antibodies reacted with swine IgG. The incubation solution of ${ }^{125} \mathrm{I}$-labelled antibodies was adjusted to an activity of $1-4.10^{6} \mathrm{cpm} / \mathrm{ml}$ with PBS containing 0.5 per cent rabbit serum albumin (RSA). After the incubation solution was removed, the wells were washed three times with PBS + Tween and dried. Finally, plates were cut up with scissors and individual wells were counted in a NRG 603 gamma counter (Tesla, Czechoslovakia) or NE 1600 (Nuclear Enterprises, U. K.). 


\section{Evaluation of Results}

The results were evaluated by comparing the activities bound in the wells containing viral antigen with those found for control antigen incubated with the same test serum dilution. If specific antiviral antibodies were present in the test serum, the activity in the wells containing viral antigen was significantly higher than in the wells containing control antigen.

The following controls were used in triplicate for each batch of viral and control antigen: During the first incubation the wells containing viral and control antigen were filled with (1) PBS +0.5 per cent BSA, (2) a frankly negative pig serum diluted 1:100, (3) a positive convalescent pig serum diluted $1: 100$. Further processing of the samples was the same as described above. In samples described under points (1) and (2), the activities bound in the wells containing viral (V) and control (C) antigen had to be almost identical, i. e. the $\mathrm{V}: \mathrm{C}$ binding ratio had to be $1.0 \pm 0.2$. In samples described under (3), the $\mathrm{V}: \mathrm{C}$ ratio had to be $\geqq 1.5$ (generally 2 to 7 ). The significance of the differences was assessed by Student's t-test. Based on the results of a number of test on several hundred serum samples, sera giving a V: C ratio of 1.5 or higher were regarded as positive, with $P$ as a rule $<0.001$ (probability of recording false positives $<0.1$ per cent). Sera giving a V: C ratio of 1.3 to 1.5 were regarded as dubious.

\section{Results}

Examination by RIA of 98 pig serum samples (96 samples from sows Nos. 1-96 and 2 samples from boars No. 97 and 98) of which 94 were positive in dilutions of $1: 2$ to $1: 512$ and 4 (samples from sows Nos. 9 and 30 and from the two boars) were negative by $\mathrm{VN}$, demonstrated specific antiviral antibodies in all serum samples from the sows. The viral and control antigens were prepared from primary pig kidney cell cultures. Part of the values obtained by RIA (sera Nos. 1-24 and 97 diluted $1: 100$ ) are presented in Table 1 . The results correspond essentially to those of the VN tests except that all 96 serum samples from

Table 1

Survey of the results obtained by RIA in 25 sera diluted 1 : 100 and comparison of the RIA and VN titre

\begin{tabular}{|c|c|c|c|c|c|c|c|}
\hline \multirow{2}{*}{$\begin{array}{l}\text { Serum } \\
\text { No }\end{array}$} & \multicolumn{2}{|c|}{$\begin{array}{l}\text { Average activity/well } \\
\text { CPM } \pm S D\end{array}$} & \multirow{2}{*}{$t$} & \multirow{2}{*}{$\mathbf{P}$} & \multirow{2}{*}{$\begin{array}{l}\text { Ratio } \\
\text { V:C }\end{array}$} & \multirow{2}{*}{$\begin{array}{l}\text { RIA } \\
\text { titre }\end{array}$} & \multirow{2}{*}{$\begin{array}{l}\text { VN } \\
\text { titre }\end{array}$} \\
\hline & Viral antigen & Control antigen & & & & & \\
\hline $\begin{array}{c}1 \\
2 \\
3 \\
4 \\
5 \\
6 \\
7 \\
8 \\
9 \\
10 \\
11 \\
12 \\
13 \\
14 \\
15 \\
16 \\
17 \\
18 \\
19 \\
20 \\
21 \\
22 \\
23 \\
24 \\
97 \\
\text { Without } \\
\text { serum }\end{array}$ & $\begin{array}{c}2303 \pm 167 \\
3480 \pm 401 \\
3686 \pm 392 \\
2726 \pm 155 \\
2641 \pm 94 \\
3625 \pm 189 \\
4337 \pm 135 \\
3437 \pm 244 \\
1937 \pm 94 \\
1824 \pm 152 \\
2905 \pm 89 \\
4178 \pm 182 \\
3835 \pm 182 \\
3475 \pm 157 \\
1614 \pm 125 \\
3170 \pm 165 \\
3308 \pm 242 \\
2294 \pm 193 \\
3028 \pm 158 \\
2407 \pm 55 \\
3028 \pm 86 \\
2665 \pm 36 \\
2552 \pm 113 \\
2741 \pm 56 \\
688 \pm 46 \\
111 \pm 34\end{array}$ & $\begin{array}{c}865 \pm 48 \\
737 \pm 19 \\
831 \pm 20 \\
1096 \pm 47 \\
850 \pm 98 \\
865 \pm 57 \\
914 \pm 13 \\
907 \pm 100 \\
1195 \pm 108 \\
913 \pm 65 \\
662 \pm 117 \\
1196 \pm 270 \\
839 \pm 60 \\
1239 \pm 93 \\
766 \pm 25 \\
948 \pm 76 \\
1020 \pm 95 \\
892 \pm 104 \\
735 \pm 87 \\
903 \pm 134 \\
713 \pm 37 \\
590 \pm 48 \\
869 \pm 92 \\
737 \pm 44 \\
751 \pm 45 \\
114 \pm 6\end{array}$ & $\begin{array}{r}14.3 \\
11.8 \\
12.6 \\
17.4 \\
22.7 \\
24.2 \\
43.7 \\
16.6 \\
9.0 \\
9.6 \\
26.4 \\
15.8 \\
27.0 \\
21.2 \\
11.4 \\
21.2 \\
15.2 \\
11.1 \\
22.0 \\
17.9 \\
42.5 \\
59.4 \\
14.1 \\
48.3 \\
-1.7 \\
-0.15\end{array}$ & $\begin{aligned}<0.001 \\
<0.001 \\
<0.001 \\
<0.001 \\
<0.001 \\
<0.001 \\
<0.001 \\
<0.001 \\
<0.001 \\
<0.001 \\
<0.001 \\
<0.001 \\
<0.001 \\
<0.001 \\
<0.001 \\
<0.001 \\
<0.001 \\
<0.001 \\
<0.001 \\
<0.001 \\
<0.001 \\
<0.001 \\
<0.001 \\
<0.001 \\
\quad- \\
\quad-\end{aligned}$ & $\begin{array}{l}2.66 \\
4.72 \\
4.43 \\
2.48 \\
3.11 \\
4.19 \\
4.74 \\
3.78 \\
1.62 \\
2.00 \\
4.38 \\
3.49 \\
4.57 \\
2.80 \\
2.10 \\
3.34 \\
3.24 \\
2.57 \\
4.12 \\
2.66 \\
4.18 \\
4.51 \\
2.93 \\
3.71 \\
0.92 \\
\\
0.97\end{array}$ & $\begin{array}{r}196830 \\
196830 \\
>196830 \\
>196830 \\
196830 \\
196830 \\
>196830 \\
196830 \\
7290 \\
24430 \\
196830 \\
>196830 \\
>196830 \\
196830 \\
65610 \\
196830 \\
>196830 \\
65610 \\
>196830 \\
>196830 \\
>195830 \\
>196830 \\
>196830 \\
196830 \\
-\end{array}$ & $\begin{array}{l}1: 2 \\
1: 32 \\
1: 128 \\
1: 16 \\
1: 8 \\
1: 16 \\
1: 128 \\
1: 32 \\
\text { neg. } \\
1: 2 \\
1: 16 \\
1: 512 \\
1: 128 \\
1: 32 \\
1: 2 \\
1: 64 \\
1: 32 \\
1: 16 \\
1: 16 \\
1: 32 \\
1: 16 \\
1: 16 \\
1: 16 \\
1: 32 \\
\text { neg. } \\
- \\
-\end{array}$ \\
\hline
\end{tabular}




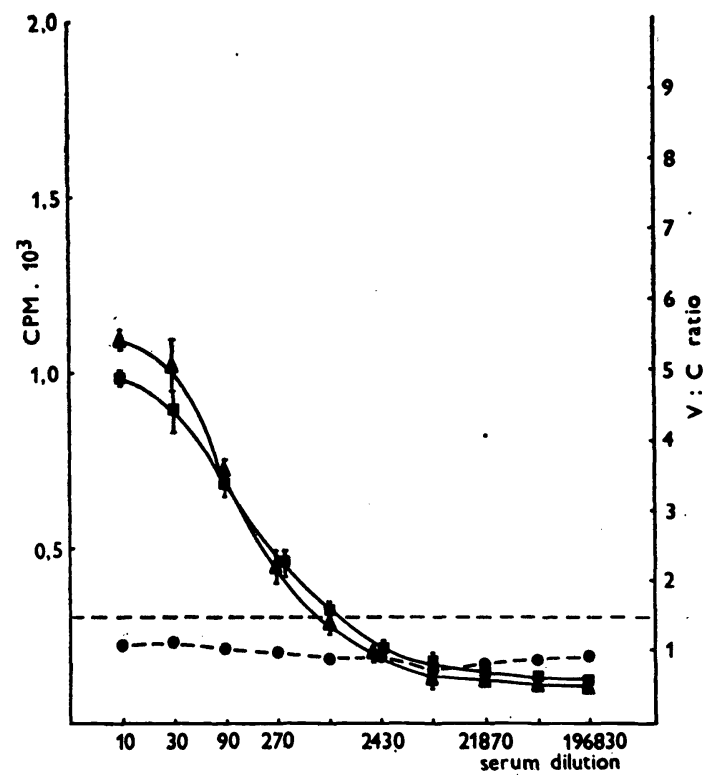

Fig. 1: serum No. 97, RIA negative, VN negative.

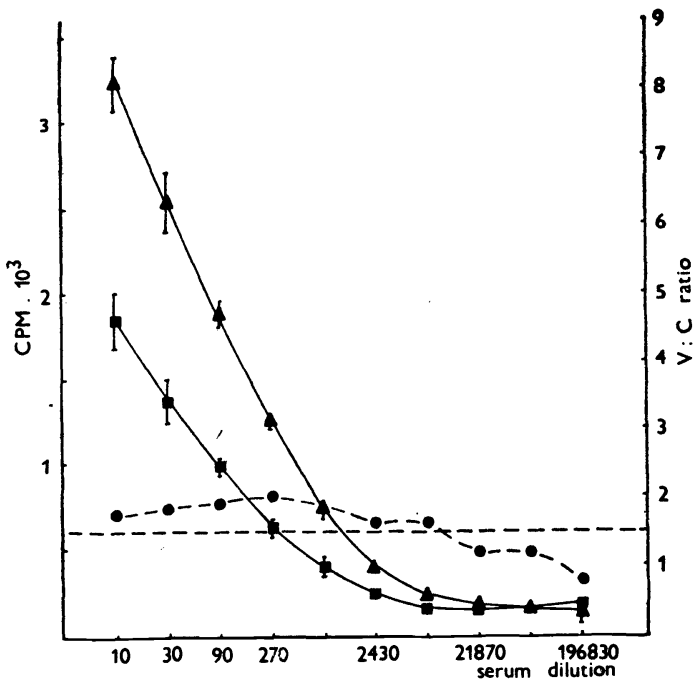

Fig. 2: serum No. 9, RIA titre 7290, VN negative.

Fig. 1-4

Survey of the results obtained by RIA in 4 blood sera Symbols :

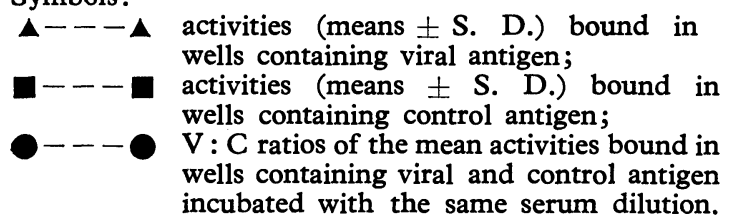

the sows were evaluated as positive owing to the higher sensitivity of the RIA technique. The only serum sample negative by RIA was that from boar No. 97. The serum of boar No. 98 showed a significant $(P<0.01)$ rise in specific antiviral antibodies, but was regarded as dubious in view of its $\mathrm{V}: \mathrm{C}$ ratio of 1.42 .

Part of the sera (Nos. 1-24 and 97) were examined in more detail to compare the antibody titres obtained by VN and RIA. The results are also summarized in Table 1 together with the values obtained for control examination without serum. Serum No. 9 that was negative by VN gave a RIA titre of 7290 . In the remaining sera positive by RIA the titres were often higher than the final serum dilution employed $(1: 196830)$. The correlation between the VN and RIA titras in individual sera was good, the difference being that the latter were as much as 10000 times higher. The results obtained by RIA in four sera, two of which were positive and two were negative by $\mathrm{VN}$, are shown graphically in Fig. 1-4, where serum dilutions are plotted against counts per minute. Closed triangles and squares indicate the means $\pm S$. D. of the activity bound to the wells containing viral and control antigen, respectively. Closed circles connected with a dashed line indicate the $\mathrm{V}: \mathrm{C}$ ratios at the individual serum dilutions.

Fig. 1 shows the results of RIA in serum No. 97 which was the only serum sample evaluated as negative by both VN and RIA. The $\mathrm{V}: \mathrm{C}$ ratios were about 1.0 in all the dilutions tested.

Fig. 2 shows the results of 
Fig. 3: serum No. 21, RIA titre $>196830$, VN titre 16.

RIA in serum No. 9 which was negative by $\mathrm{VN}$. The $\mathrm{V}: \mathrm{C}$ ratio $>1.5$, which was selected by us as the lower limit for positive evaluation, was recorded in serum dilutions ranging from $1: 10$ to $1: 7290$. The levels of specific antiviral antibodies were relatively low and the highest $\mathrm{V}: \mathrm{C}$ ratios (1.90 and 1.99) were obtained with serum dilutions of $1: 90$ and $1: 270$, respectively.

Fig. 3 shows the results obtained with serum No. 21, the VN titre of which was 16 . The concentration of antiviral antibodies being high, the highest $\mathrm{V}$ : C ratio, 9.09, was obtained in the serum dilution of $1: 2430$. With serum dilutions of $1: 90$ and $1: 270$, the $\mathrm{V}: \mathrm{C}$ ratios were lower, but still very high (4.90 and 7.10 , respectively). The serum was positive beyond the dilution of 196830 .

Fig. 4 shows the results obtained with serum No. 12, the VN titre of which was 512 . Since the concentration of antiviral antibodies was remarkably high, the activity bound to viral antigen was approximately at the same level up to the dilution of $1: 270$ and it was only at the higher dilutions that the normal pattern of the curve was observed. In agreement with this, the highest V : C ratio, 13.63, was obtained in the serum dilution of $1: 7290$. With serum dilutions of $1: 90$ and $1: 270$ the $\mathrm{V}: \mathrm{C}$ ratios were 4.38 and 7.08 , respectively. The serum was positive beyond the dilution of 1 : 196830 .

Fig. 4: serum No. 12, titre > 196830 , VN titre RIA 512.
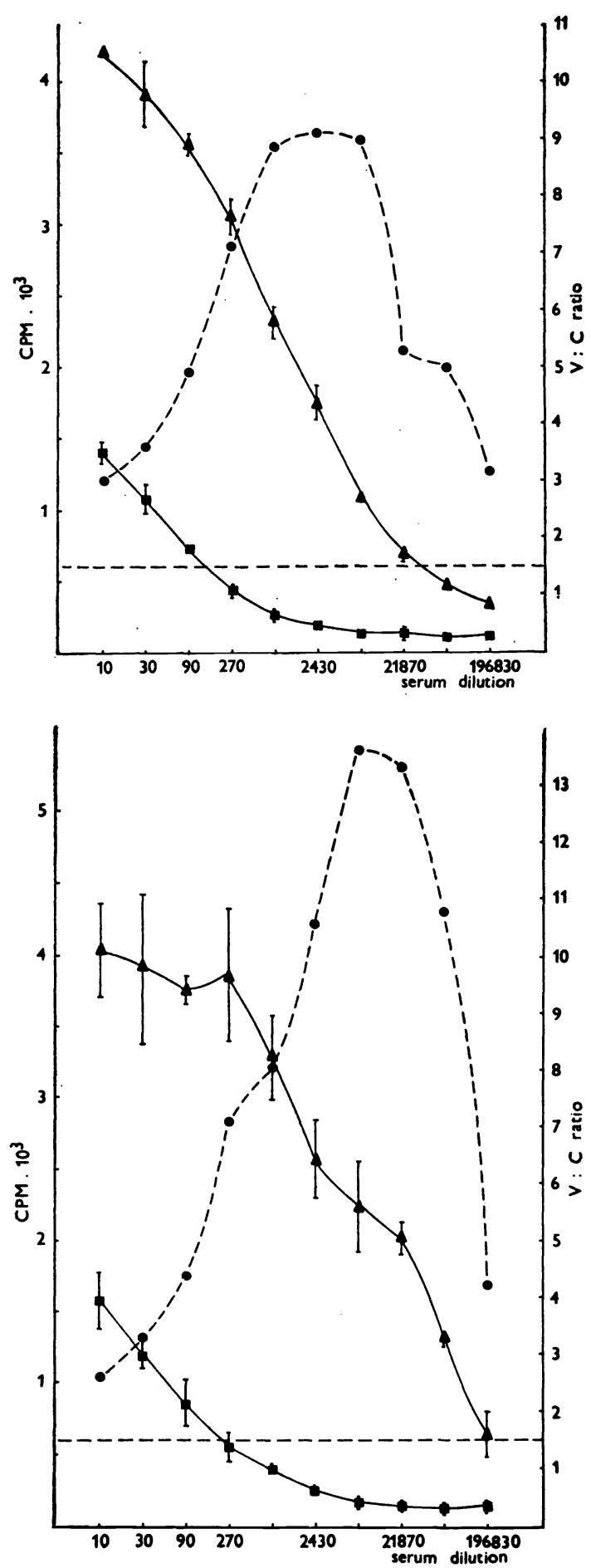


\section{Discussion}

Up to now, radio- and enzymimmunological methods of determining antiviral antibodies in the blood serum or other body fluids have been used as diagnostic tools mainly in human medicine or in experimental animals infected with viruses pathogenic for man (herpes simplex, influenza, parainfluenza, vaccinia, rubella, St. Louis encephalitis, hepatitis $\mathrm{A}$ and $\mathrm{B}$, measles, cytomegalovirus, Epstein-Barr, reoviruses, and other viruses).

With the growing economic impact of some animal diseases in large herds, it has become imperative that highly sensitive diagnostic methods be adopted also in veterinary medicine.

The results obtained by RIA in the sera from naturally infected pigs show that the RIA technique is approximately 10000 times more sensitive than the VN test. Thanks to its sensitivity, the RIA can detect even very small quantities of antiviral antibodies in sera that are evaluated as negative by VN.

The present results also suggest that serum dilutions at which optimum V:C ratios are achieved depend on the concentration of antiviral antibodies in the serum and range between $1: 90$ and $1: 7290$. For routine examination of field samples it is desirable to choose a dilution at which weakly and highly positive sera may be evaluated with reasonable reliability. For this purpose a serum dilution range of $1: 90$ to $1: 270$ is convenient. The lowest dilution used routinely in our laboratory was $1: 100$.

The advantages of the RIA over the conventional VN test in the diagnosis of Aujeszky's disease of pigs may be summarized under the following points:

The RIA of the sera can be completed within two days and in urgent cases within one day, whereas the VN test requires three days to perform provided that cell cultures have been prepared.

Neither aseptical conditions, nor costly operation of virological laboratories, nor preparation of cell cultures are required. Stored adequately (in sealed ampoules at $-70^{\circ} \mathrm{C}$ ), viral and control antigens are available at any time and can be used for several months. In our experiments the antigens were routinely used after storage for more than one year.

The RIA is more specific and approximately 10000 times more sensitive than the VN test. Its high sensitivity makes it possible to reveal pigs with Aujeszky's disease earlier and with more reliability than does the VN test. This makes the RIA a widely applicable diagnostic tool in the control of Aujeszky's disease in the field.

Similar advantages of RIA, particularly the rapidity with which it can be performed and the fact that aseptic conditions are not required, were pointed out by other investigators using direct RIA (Döller and Jakubik 1980), indirect RIA (Kelling et al. 1978) or ELISA (Briaire et al. 1979, Toma et al. 1979).

Somewhat conflicting observations were made by the aforementioned writers on the sensitivity of the individual methods. With indirect methods using anti-immunoglobulin antibody labelled with radioisotope or conjugated with enzyme, ELISA was reported to be many times (Briaire et al. 1979, Toma et al. 1979) and RIA 2 to 32 times (Kelling et al. 1978) as sensitive as the VN test.

On the other hand, Döller and Jakubik (1980), working with direct RIA using ${ }^{122} \mathrm{I}$-labelled viral antigen, claimed that the method was 320 to 150000 times as sensitive as the VN test. From their results they inferred that direct RIA has the following advantages over indirect RIA: it is considerably more sensitive, 
requires a smaller quantity of purified antigen and provides the possibility of using labelled antigen for examination of samples from various animal species.

From our results, however, it appears that indirect RIA, too, is as much as 10000 times as sensitive as the VN test. Moreover, the indirect method allows one to use ${ }^{125}$ I-labelled antibodies for examination of pig sera for the presence of antibodies against a variety of other antigens. The quantity of viral antigen consumed is also negligible. In contrast to all the aforementioned investigators who carried out their RIAs or ELISAs with concentrated and purified viral antigen, we used with success as viral antigen an infectious fluid prepared merely by freezing and thawing of infected cell cultures.

It can be concluded that direct and indirect RIA methods are more or less equally sensitive and both have their merits. A deciding factor in the sensitivity of indirect RIA is the quality of antibodies against swine immunoglobulins. In our experience, ELISA is 10 to 100 times less sensitive than indirect RIA when the same antibodies are used. Further details will be reported in another paper.

\section{Využití solid-phase radioimmunoassay (RIA) $\mathbf{k}$ diagnostice Aujeszkého choroby u přirozeně infikovaných prasat}

Je popsáno vypracování a využití nepř́mé solid-phase radioimmunoássay (RIA) $k$ diagnostice Aujeszkého choroby u přirozeně infikovaných prasat. Metoda je založena na stanovení specifických antivirových protilátek v krevním séru. Ve srovnání $s$ běžně používaným virusneutralizačním testem je provedení RIA metody rychlejší, nevyžaduje sterilní podmínky a zjištoované titry protilátek jsou asi $10000 \times$ vyšší. Je naznačena možnost využití RIA metody v široké diagnostické praxi.

\section{Использование радиоиммунологического опробования (РИА) для диагностики болезни Ауески у естественным путем инфицированных свиней}

Приводится описание разработок и использования косвенного радиоиммунологического опробования (РИА) для диагностики болезни Ауески у свиней, инфицированных естественным путем. Метод основан на определении специфических антивирусных противотел в кровяной сыворотке. По сравнению с обычно ислользуемым вируснейтрализационным тестом метод РИА проводят гораздо быстрее, не требуются стерильные условия и устанавливаемые титры противотел приблизительно 10000 раз выше. Отмечается возможность широкого использования данного метода в диагностировании.

\section{References}

ARSTILA, P. - VUORIMAA, T. - KALIMO, K. - HALONEN, P. - VILJANEN, M. GRANFORS, K. - TOIVANEN, P.: A solid-phase radioimmunoassay for IgG and IgM antibodies against measles virus. J. gen. Virol. 34, 1977: 167-176.

BRIAIRE, J. - MELOEN, R. H. - BARTELING, S. J.: An enzyme-linked immunosorbent assay (ELISA) for the detection of antibody against Aujeszky's disease virus in pig sera. Zbl. Vet. Med. B, 24, 1979: 76-81.

DÖLLER, G. - JAKUBIK, J.: Direkter Festphasen-Radioimmunoassay zum Nachweis von Aujeszkyvirus-Antikörpern. Zbl. Bakt. Hyg., Abt. Orig. A 247, 1980: 1-7. 
FORGHANI, B. - SCHMIDT, N. J. - LENNETTE, E. H.: Solid-phase radioimmunoassay for typing Herpes simplex viral antibodies in human sera. J. clin. Microbiol. 2, 1975: 410-418.

FORGHANI, B. - SCHMIDT, N. J. - LENNETTE, E. H.: Sensitivity of a radioimmunoassay method for detection of certain viral antibodies in sera and cerebrospinal fluids. J. clin. Microbiol. 4, 1976: 470-478.

HUTCHISON, H. D. - ZIEGLER, D. W.: Simplified radiomimunoassay for diagnostic serology. Appl. microbiol., 24, 1972: $742-749$.

HUTCHISON, H. D. - ZIEGLER, D. W.: Criteria for preparing, evaluating and standartizing iodinated globulins for radioimmunoassay procedures. Appl. microbiol. 28, 1974: 935-42.

KALIMO, K. O. K. - MARTILA, R. J. - GRANFORS, K. - VILJANEN, M. K.: Solid-phase radioimmunoassay of human immunoglobulin $M$ and immunoglobulin $G$ antibodies against herpes simplex virus type 1 capsid, envelope, and excreted antigens. Infect. Immun. 15, 1977: 883-889.

KELLING, C. L. - STAUDINGER, W. L. - RHODES, M. B.: Indirect solid-phase microradioimmunoassay for detection of pseudorabies virus antibody in swine sera. Am. J. vet. Res., 39, 1978: 1955-1957.

McCONAHEY, P. J. - DIXON, F. J.: A method of trace iodination of proteins for immunological studies. Int. Archs. Allergy appl. Immun., 29, 1966: 185-189.

MEUERMAN, O. H. - ARSTILA, P. P. - PANELIUS, M. - REUNANEN, M. K. VILJANEN, M. K. - HALONEN, P. E.: Solid-phase radioimmunoassay detection of rubella virus IgG antibody in serum and CSF of patients with multiple sclerosis. Acta path. microbiol. Scand. B, 85, 1977: 113-116.

MEURMAN, O. H. - VILJANEN, M. K. - GRANFORS, K.: Solid-phase radioimmunoassay of rubella virus immunoglobulin $M$ antibodies: comparison with sucrose density gradient centrifugation test. J. clin. Microbiol. 5, 1977: 257-262.

PATTERSON, W. R. - SMITH, K. O.: Improvements of a radioimmunoassay for measurement of viral antibody in human sera. J. clin. Micrboiol. 2, 1975: 130-133.

PURCELL, R. H. - WONG, D. C. - MORITSUGU, Y. - DIENSTAG, J. L. - ROUTENBERG, J. A. - BOGGS, J. D.: Microtiter solid-phase radioimmunoassay for hepatitis A-antigen and antibody. J. Immunol., 116, 1976: 349-356.

RODÁK, L. - ŚMÍD, B. - SEDLÁČEK, M.: A radioimmunoassay for anti-virus antibodies in farm animals. Radiochem. radioanal. Letters, 34, 1978: 241-246.

ROSENTHAL, J. D. - HAYASHI, K. - NOTKINS, A. L.: Rapid microradioimmunoassay for the measurement of antiviral antibody. J. Immunol., 109, 1972: 171-173.

SMITH, K. O. - GEHLE, W. D. - MCCRACKEN, A. W.: Radioimmunoassay techniques for detecting naturally occurring antibody in human sera. J. immun. Meth., 5, 1974: 337-344.

TOMA, B. - MOUTOU, F. - FORTIER, B.: Recherche des anticorps anti-virus de la maladie d'Aujeszky par la technique ELISA. Rec. Méd. Vét., 155, 1979: 455-463. 